\title{
Kryminały \\ jako literatura światowa
}

Stewart King

Już od swoich dziewiętnastowiecznych początków po dziś dzień opowieści kryminalne przekraczały granice oraz języki, a wszędzie, gdzie dotarły, pisarze dostosowywali je i przepisywali, aby zaspokoić własne wyjątkowe zainteresowania. Jednak mimo międzynarodowego rozpowszechnienia prozy kryminalnej (crime fiction) oraz powodzenia pisarzy kryminałów z całego świata, takich jak Agatha Christie, Georges Simenon, Dashiel Hammet czy (bardziej współcześnie) Henning Mankell, Natsuo Kirino, Qiu Xiaoling, Fred Vargas i James Lee Burke, mało kto próbował zrozumieć ten gatunek w jego ogólnoświatowym kontekście. Celem tego artykułu jest zbadanie międzynarodowych wymiarów prozy kryminalnej poprzez wpasowanie jej w ramy literatury światowej. W ten sposób można postawić następujące pytania: Po co badać prozę kryminalną jako literaturę światową? Jakie związki istnieją pomiędzy badaniami nad narodową prozą kryminalną a perspektywą literatury światowej? I jaką formę lub formy mogą przyjąć studia nad światową prozą kryminalną?

Omawiane tu przykłady pochodzą głównie z krytyki anglojęzycznej prozy kryminalnej ${ }^{1}$. W 1991 roku John G. Cawelti zauważył, że krytyka kryminałów (mystery fiction) pozostaje daleko w tyle, jeśli chodzi o „regionalizację oraz internacjonalizację opowieści detektywistycznych (detective story)” ${ }^{2}$, a w swojej późniejszej pracy narzekał, że „angielscy i amerykańscy naukowcy są w dużej mierze nieświadomi badań prowadzonych przez Francuzów i Niemców”3. Opinię Caweltiego potwierdzają liczne wstępy naukowe do prozy kryminalnej, które na pierwszym miejscu stawiają anglo-amerykański kanon i albo zupełnie ignorują teksty pisane w innych językach, albo traktują je pobieżnie. Jednym z takich przykładów jest Cambridge Companion to Crime Fiction, w którym Martin Priestman, redaktor skądinąd znakomitego wstępu, stwierdza, że proza kryminalna jest „raczej wielopoziomowa niż jednokierunkowa”" , ale sam zbiór wcale tego nie obra-

\footnotetext{
${ }^{1}$ Potrzeba dalszych badań, by określić, czy krytyka prozy kryminalnej powstająca w językach innych niż angielski podąża za omawianą $\mathrm{w}$ dalszej części artykułu tradycją narodową, czy też podejmuje więcej wysiłku, by zrozumieć prozę kryminalną w jej globalnym kontekście.

2 J.G. Cawelti, Detecting the Detective [Wykrywając detektywa], ANQ 12.3, 1999, s. 54.

${ }^{3}$ Tegoż, Mystery, Violence, and Popular Culture [Tajemnica, przemoc i kultura popularna], Madison 2004, s. 311.

${ }^{4}$ The Cambridge Companion to Crime Fiction, red. M. Priestman, Cambridge, UK 2003, s. 6.
} 
zuje - składa się bowiem $\mathrm{z}$ artykułów na temat anglo-amerykańskich narracji kryminalnych, z jednym wyjątkiem: pojedynczym rozdziałem o francuskim kryminale autorstwa Sity Schütt ${ }^{5}$.

Od czasu kiedy Cawelti wezwał badaczy prozy kryminalnej, by szerzej zajęli się narracjami (detective, mystery, crime) spoza głównego nurtu i nieanglojęzycznymi, coraz więcej naukowców zaczęło się nimi interesować, pisząc książkowe studia o kryminalnych narracjach z Francji (Gorrara, Hutton), Włoch (Past, Pezzotti, Pieri), Półwyspu Iberyjskiego (Godsland, Vosburg), Japonii (Kawana, Seaman), Kuby i Meksyku (Braham, Uxó) oraz Skandynawii (Forshaw, Nestingen i Arvas) ${ }^{6}$. Mimo niewątpliwie rozrastających się kryteriów literatury mystery oraz zwiększającej się świadomości różnorodnych praktyk w obrębie prozy kryminalnej na całym świecie, tym badaniom nie udało się złamać monopolu anglo-amerykańskiego kanonu - nadal znajduje się on na pierwszym planie i w centrum, podczas gdy badania nad literaturami narodowymi są odsyłane na marginesy, a pomiędzy nimi nie nawiązuje się niemal żaden krytyczny dialog?

Co więcej, choć prace te pomagają zwiększyć świadomość różnorodności narracji kryminalnych na całych świecie, badania na ich temat, które leżą poza anglo-amerykańskim polem zainteresowania, podobnie jak analizy oparte na tym kanonie rzadko ukazują globalny wymiar pisarstwa kryminalnego. Do pewnego stopnia te badania same przyczyniają się do własnej marginalizacji w kontekście krytyki prozy kryminalnej, ponieważ ograniczają obiekt swoich zainteresowań do konkretnej narodowej lub regionalnej tradycji literackiej. W tych badaniach narodowej prozy kryminalnej można dostrzec pewien schemat, który Franco Moretti nazywa „prawem literackiej ewolucji”" [wyróżnienie autora], przez co ten światowy gatunek zostaje ograniczony narodowo. Wynika to z tego, że wśród pisarzy konkretnej narodowej tradycji, w której pracuje dany badacz, kładzie się nacisk przede wszystkim na rozwój produkcji prawdziwie autochtońskich narracji kryminalnych. Analizy prowadzone według tego wzorca zaczynają się zwykle od przełożenia obcych - głównie anglo-amerykańskich lub francuskich - modeli, takich jak nowele i opowiadania Edgara Allana Poego, Arthura Conana Doyle'a, Agathy Christie, Dashiella Hammetta, Raymonda Chandlera czy Georges'a Simenona na język narodowy. W drugim etapie naukowcy identyfikują i oceniają kryminalne narracje autorstwa lokalnych pisarzy w zależności od tego, w jakim stopniu naśladują obce wzorce lub przyczyniają się do powstania narodowej prozy kryminalnej. Na przykład na moim własnym polu - prozy kryminalnej z Hiszpanii - krytycy stwierdzają, że gatunek ten pojawił się w hiszpańskiej literaturze późno, a za pierwszą powieść detektywistyczną uznają La gota de sangre [„Kropla krwi”, 1911] stworzoną przez pisarkę naturalizmu Emilię Pardo Bazán (patrz rys. 1). Jednak, mimo że tę artystkę chwali się za wprowadzenie nowego gatunku do hiszpańskiej literatury, jest jednocześnie krytykowana, ponieważ La gota de sangre krytycy uważają „bardziej za naśladownictwo obcych modeli niż możliwość

\footnotetext{
${ }^{5}$ Dwie inne prace potwierdzające ten trend to Twentieth-Century Crime Fiction: Gender, Sexuality and the Body [Dwudziestowieczna proza kryminalna: płeć, seksualność i ciało] Gill Plain oraz Crime Fiction [Proza kryminalna] Johna Scaggsa. Mimo szeroko zakrojonych tytułów Plain bada tylko dzieła anglojęzyczne, a praca Scaggsa zawiera powierzchowne odniesienia do dzieł francuskich oraz omówienie Imienia róży Umberta Eco.

6 Badania anglo-amerykańskiej fikcji spoza mainstreamu obejmują monografie o prozie kryminalnej żydowskiej (Roth), afroamerykańskiej (Pepper, Soitos, Gifford) oraz rdzennych mieszkańców Ameryki (Browne, Rodriguez). Ta lista jest ograniczona do prac anglojęzycznych, w związku z czym nie bierze pod uwagę szerokiego zbioru badań powieści detektywistycznych autorstwa naukowców publikujących w językach innych niż angielski.

7 Wyjątkiem jest tu French and American Noir: Dark Crossings [Francuski i amerykański noir. Mroczne przecięcie] Alistaira Rollsa i Deborah Walker (2009).

${ }^{8}$ F. Moretti, Przypuszczenia na temat literatury światowej, przeł. P. Czapliński, „Teksty Drugie” 2014, nr 4, s. 136.
} 
stworzenia autochtonicznej prozy kryminalnej"9. Badacze potępiają także fakt, że w okresie od ostrożnych kroków Emilii Pardo Bazán w nowym gatunku aż po lata siedemdziesiąte XX wieku, większość pisarzy kryminałów z Hiszpanii miała w zwyczaju odtwarzanie zagranicznych wzorców, ponieważ podobno autorzy odpowiadali na oczekiwania czytelników i osadzali swoje opowieści za granicą, w egzotycznych lokalizacjach, a także zaludniali je zagranicznymi bohaterami. W wielu przypadkach ta praktyka narodowego literackiego transwestytyzmu była uzupełniana o używanie obcych (zwykle angielskich lub pseudoangielskich) pseudonimów oraz dodawanie fikcyjnych angielskich tytułów, z których te powieści miały być rzekomo tłumaczone na hiszpański ${ }^{10}$. Tak robiła na przykład Fernanda Cano, pisząca jako Mary Francis Colt - w latach 1953-1963 wydała 13 powieści w tej rzekomo swojskiej angielskiej tradycji.

Badacze hiszpańskiej prozy kryminalnej nie uznają takich pisarek jak Cano czy Colt za autentycznie hiszpańskie, w związku z czym rzadko spotykają się one z zainteresowaniem krytyków w kontekstach bardziej poważnych niż anegdotki. Zamiast tego naukowcy są znacznie bardziej zainteresowani tak zwanymi autentycznymi dziełami hiszpańskiej prozy kryminalnej, której prawowita narodowość jest potwierdzona przez „postaci, które otwarcie obnoszą się z typowymi hiszpańskimi cechami osobowości oraz ich językiem [...] i sytuacjami przedstawianymi w hiszpańskich powieściach detektywistycznych [które], choć w pewnym stopniu uniwersalne, są zawsze bezpośrednią odpowiedzią na społeczne konflikty typowe dla hiszpańskiej rzeczywistości”" ${ }^{11}$.

Zarysowany tu rozwój hiszpańskiej prozy kryminalnej - od tłumaczeń, poprzez imitacje, po oryginalną twórczość - odzwierciedla sposób, w jaki krytycy zwykle obrazują rozwój opowieści kryminalnych poza kanonem anglo-amerykańskim (zob. np. Pieri, Seaman). Takie podejście skupia się przede wszystkim na rozwoju narodowej tradycji literackiej kosztem międzynarodowych związków pomiędzy pracami. To zrozumiałe, skoro badacze literatury zwykle działają w obrębie wydziałów uniwersyteckich skupionych na językach angielskim, chińskim, francuskim, niemieckim, włoskim, japońskim, rosyjskim, hiszpańskim lub językach skandynawskich; i muszą się podporządkować instytucjonalnym naciskom, by tworzyć stypendia w swoich dziedzinach. Oczywiście celem tego artykułu nie jest nadszarpnięcie słuszności tych narodowych perspektyw - to ważne, aby rozumieć, jak dany gatunek rozwija się w konkretnej społeczności oraz jak lokalni pisarze przyswajają go i adaptują, by służył ich własnym celom. Mimo wszystko jednak ten artykuł przekonuje do denacjonalizacji badań nad prozą kryminalną. W miejsce narodowych ram, które zdominowały obecne praktyki badawcze, proponuje czytanie prozy kryminalnej jako przykładu literatury światowej - co pozwala zyskać lepszy wgląd w globalny zasięg tego gatunku.

Od samego zarania jej koncepcji literatura światowa starała się unikać ograniczeń tradycji narodowych. W jednym z najwcześniejszych zastosowań tego terminu Goethe sugerował, że „[1]iteratura narodowa dzisiaj nie przedstawia już niczego istotnego, ponieważ „poezja jest wspólnym dobrem całej ludzkości oraz że wszędzie i we wszystkich epokach występuje u wielu

\footnotetext{
${ }^{9}$ J. Valles Calatrava, La novela criminal española, Granada 1991, s. 91. Wszystkie tłumaczenia z hiszpańskiego za tłumaczeniami autora na angielski.

${ }^{10}$ Stosowanie angielskich pseudonimów było również powszechne we włoskiej prozie kryminalnej aż do lat dziewięćdziesiątych XX wieku, por. G. Turnaturi, The Invention of a Genre: The Mediterranean Noir [Powstanie gatunku. Śródziemnomorski noir], przeł. K. Mascorro i M. Orton, [w:] The Arts and History [Sztuki i historia], red. G. Parati, Madison, NJ 2012, s. 55.

${ }^{11}$ J.F. Colmeiro, La novela policiaca española. Teoría e historia crítica, Barcelona 1994, s. 265.
} 
tysięcy ludzi”12. Goethe uważał, że aby pełniej zrozumieć literaturę, powinniśmy wziąć przykład z jego podejścia i „szukać... w obcych narodach”, bo „wkraczamy w erę literatury świa-

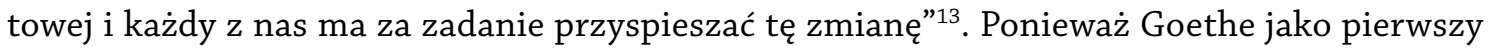
naszkicował swoją wizję literatury światowej, badacze mieli problem ze zdefiniowaniem tego nieuchwytnego terminu. Czy chodzi o całą literaturę, która została stworzona wszędzie w historii? Czy ogranicza się do pewnego wyboru arcydzieł literackich z całego świata? Jaki ma związek z literaturami narodowymi? I, jeśli skupiamy się na temacie prozy kryminalnej, jakie są konsekwencje badania kryminalnych narracji z całego świata?

Praktykę literatury światowej można ograniczyć do dwóch szerokich rodzajów: inkluzywnej i ekskluzywnej. Rozwijając tak zwaną transkulturową analizę literacką, szwedzki badacz Anders Pettersson utrzymuje, że na badanie literatury nie można nakładać „żadnych określonych z góry narodowych lub czasowych ograniczeń” ${ }^{14}$. Pettersson przyznaje, że „istnieje taka tendencja, by uważać zjednoczone literatury światowe za coś, co jest zwyczajnie zbyt obszerne, by można było to rozważać"15, ale przekonuje też, że naukowcy z kontynentu europejskiego właśnie to robią - cytuje przy tym wiele przykładów, w tym niemiecką New Handbook of Literary Studies [Nowy podręcznik badań literackich] wydaną w 25 tomach jako dowód, że można stworzyć światowe historie literatury.

David Damrosch oraz Claudio Guillén przyznają, że literatura światowa opisana w transkulturowej literaturze Petterssona „może w pewnym sensie istnieć jako idealny porządek, hipotetyczny koncept myślowy"16, ale jednocześnie przekonują, by poddawać literaturę światową bardziej restrykcyjnym interpretacjom. Guillén nazywa inkluzywne podejście „szalonym pomysłem, w praktyce niemożliwym, niewartym uwagi prawdziwego czytelnika, a co najwyżej oszukującego się archiwisty”" a Damrosch „kategorią, w której nie można wskazać niczego przydatnego”" W jej miejsce Damrosch sugeruje przyjąć, że literatura światowa zawiera „wszystkie dzieła literackie krążące w obiegu kultury swojego pochodzenia - zarówno w przekładzie, jak i w języku

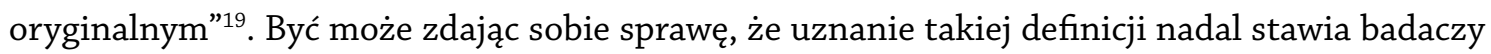
w obliczu ogromnego pola literackiego, Damrosch wskazuje kolejne ramy; ogranicza literaturę światową do znaczenia każdego tekstu w każdym konkretnym momencie: „dzieło skutecznie funkcjonuje jako literatura światowa tylko i wyłącznie wtedy, gdy rzeczywiście jest obecne w systemie literackim poza swoją kulturą oryginalną [wyróżnienie oryginalne]”20.

Istnieje wiele powieści kryminalnych, które potwierdzają kryterium Damroscha i Guilléna do uznania tekstu za dzieło literatury światowej - zwłaszcza powieści Christie i Simeona. Christie, której

${ }^{12}$ J.P. Eckermann, Rozmowy z Goethem, przeł. K. Radziwiłł, J. Zeltzer, t. 1, Warszawa 1960, s. 333.

${ }^{13}$ Tamże.

${ }^{14}$ A. Pettersson, Transcultural Literary History: Beyond Constricting Notions of World Literature [Transkulturowa historia literatury. Poza powstaniem pojęcia literatury światowej], „New Literary History” 2008, nr 39, s. 463.

${ }^{15}$ Tamże, s. 466.

${ }^{16}$ D. Damrosch, What is world literature? [Czym jest literatura światowa?], Princeton 2003, s. 111.

${ }^{17}$ C. Guillén, The Challenge of Comparative Literature [Wyzwania komparatystyki literackiej], Cambridge, MA 1993, s. 39.

${ }^{18}$ D. Damrosch, What is world literature?, s. 110.

${ }^{19}$ Tamże, s. 4.

${ }^{20}$ Tamże. 
książki zostały przetłumaczone na ponad 100 języków, sprzedała bilion egzemplarzy po angielsku i drugi bilion w innych językach, jest podobno bestsellerową pisarką wszech czasów. Podobnie w połowie lat osiemdziesiątych szacowano, że urodzony w Belgii Simeon był najczęściej czytanym pisarzem na Ziemi ${ }^{21}$. Tych dwoje twórców stanowi być może najbardziej znane przykłady pisarzy kryminałów, których dzieła powstają w dużym oddaleniu od publiczności, dla której zostały oryginalnie stworzone. Z bardziej współczesnych przykładów - skandynawski kryminał (Nordic noir) z takimi pisarzami, jak Henning Mankell, Stieg Larsson i Camilla Läckberg jest trwałym dowodem międzynarodowego znaczenia tego gatunku, a więc i jego miejsca w obrębie literatury światowej.

Świat „literackości” prozy kryminalnej jest nie tylko oczywisty dzięki mnogości języków, na które tłumaczy się daną powieść czy danych światowej sprzedaży. Mimo że są to istotne wyznaczniki, dzieła i autorów wchodzących do panteonu światowej literatury kryminalnej można identyfikować poprzez liczne odniesienia intertekstualne do wcześniejszych utworów i pisarzy pojawiających się w kryminalnych narracjach na całym świecie. Jako przykłady mogą tu posłużyć dwaj pisarze jeden japoński, drugi kataloński: Taro Hirai oraz Jaume Fuster. Taro Hirai wyraża na przykład swoją wdzięczność autorowi Zabójstwa przy Rue Morgue w swoim nom de plume - Edogawa Rampo, a Jaume Fuster przyznaje się do wpływów Rossa Macdonalda oraz Dashiella Hammetta w swoim tomie opowiadań Les claus de vidre („Szklane klucze”), w którym występuje detektyw Lluís Arquer, czyli katalońska wersja prywatnego detektywa stworzonego przez Macdonalda, Lew Archera ${ }^{22}$.

Mimo że globalny zasięg prozy kryminalnej w przekładzie i w oryginale powinien stanowić idealny przykład literatury światowej, jej wyznawcy w większości ignorują ten gatunek, może $\mathrm{z}$ wyjątkiem nauczania ${ }^{23}$. Brak prozy kryminalnej w badaniach literatury światowej może wynikać ze skupienia na tak zwanych dziełach kultury wysokiej - tych tekstach literackich, które uważa się za warte badań i tłumaczeń poza krajem, w którym powstały. Dowodzą tego tytuły popularnych antologii literatury światowej, takie jak The Best of the World's Classics (1909), The Harvard Classics (1910), Masterpieces of World Literature in Digest Form (1949) oraz Norton Anthology of World Masterpieces (1956). Bardziej współczesne antologie, np. sześciotomowa Longman Anthology of World Literature (2004) czy Norton Anthology of Western Literature (2004, 8. wydanie) są może bardziej otwarte na teksty spoza kanonu, ponieważ zawierają dzieła folkloru i piosenki popularnej, jednak także wykluczają współczesne teksty kultury popularnej, takie jak fantastyka naukowa, erotyka, fantastyka i oczywiście proza kryminalna.

Wykluczenie prozy popularnej z badań nad literaturą światową powiela podział, który i tak już istnieje w badaniach literackich. Jak twierdzi Ken Gelder „często można odnieść wrażenie, że Literatura i literatura popularna istnieją w nieustannym stanie wzajemnego odrzucania i odpychania"24.

\footnotetext{
${ }^{21}$ D. Platten, Origins and Beginnings: The Emergence of Detective Fiction in France [Źródła i początki. Powstanie prozy detektywistycznej we Francji], red. C. Gorrara, Cardiff 2009, s. 15.

${ }^{22}$ Choć cytowane przykłady demonstrują wpływ anglo-amerykańskich modeli na nieangielskojęzycznych pisarzy kryminałów, taki wpływ nie zawsze pochodzi ze Stanów Zjednoczonych czy Wielkiej Brytanii. Na przykład sycylijski autor Andrea Camilleri pokazuje swój szacunek dla hiszpańskiego autora Manuela Vázquez Montalbána, nazywając bohatera swojej serii Salvo Montalbano.

${ }^{23}$ Por. P.P. Buckler, Teaching International Detective Fiction [Ogólnoświatowe nauczanie prozy detektywistycznej], [w:] Murder 101: Essays on the Teaching of Detective Fiction, red. E.J. Rielly, Jefferson 2009, s. 25-7.

${ }^{24} \mathrm{~K}$. Gelder, Popular Fiction: The Logics and Practices of a Literary Field [Proza popularna. Logika i praktyki pola literackiego], London 2004, s. 11.
} 
W takim schemacie literatura światowa reprezentuje jakość, a „jej podstawowe wartości nazywane są oryginalnością, złożonością, spójnością, autonomią, wyjątkowością, wielopoziomowością, ponadczasowością, i tak dalej”, podczas gdy cechą wyróżniającą prozę popularną jest ilość „a jej kredo to zlepek wartości określanych takimi pojęciami jak zaskoczenie czy nowatorstwo..., format czy gatunek (i, na bardziej mikrostylistycznym poziomie, schematyczne pisanie), sensacyjność i voyeuryzm... oraz wreszcie heteronomia" ${ }^{25}$. Wygląda na to, że podstawowa motywacja badań literatury światowej polega na tym, że jeśli ktoś chce analizować teksty pomiędzy tradycjami narodowymi, powinien wybierać dzieła najwyższej jakości, które usprawiedliwiają czas i wysiłek włożony w wykraczanie poza tradycję narodową.

Podczas gdy badacze literatury światowej zignorowali powieść detektywistyczną, specjaliści od kryminałów próbują lepiej zrozumieć światowy zasięg tego gatunku. Można to zaobserwować w kilku opublikowanych dotąd pracach dotyczących tak zwanej międzynarodowej prozy kryminalnej. Te prace - Investigating Identities: Questions of Identity in Contemporary International Crime Fiction [„Badanie tożsamości: Pytania o tożsamość we współczesnej międzynarodowej prozie kryminalnej”] (2009) pod redakcją Marieke Kranjenbrink oraz Kate M. Quinn; The Foreign in International Crime Fiction: Transcultural Representations [„Obcy w międzynarodowej prozie kryminalnej: Reprezentacje transkulturowe"] (2012) pod redakcją Jean Anderson, Caroliny Mirandy oraz Barbary Pezzotti, jak również zbiór Detecting Detection: International Perspectives on the Uses of a Plot [,Wykrywając śledztwo: Międzynarodowe perspektywy na wykorzystanie fabuły"] (2012) pod redakcją Petera Bakera i Deborah Shaller - odzwierciedlają inkluzywne podejście Peterssona i nie stawiają żadnych ograniczeń badaniom prozy kryminalnej. Dzięki temu te wspaniałe zbiory zawierają przykłady kryminałów z całego świata, łącznie z Chinami, Francją, wyspami Australii i Oceanii, Australią, Austrią, Rosją, Kubą, Indiami oraz Włochami. Światowy wymiar prozy kryminalnej jest również analizowany w badaniach postkolonialnych kryminałów, na przykład w The Post-Colonial Detective [Postkolonialny detektyw] (2001) pod redakcją Eda Christiana, Postcolonial Postmortems: Crime Fiction from a Transcultural Perspective [Postkolonialne postmortem: Proza kryminalna z perspektywy transkulturowej] (2006) pod redakcją Christine Matzke oraz Susanne Mühleisen, czy Detective Fiction in a Postcolonial and Transnational World [Proza detektywistyczna w postkolonialnym i transnarodowym świecie] (2009) pod redakcją Nelsa Pearsona i Marca Singera. Mimo wszystko, choć można wskazać pewne wyjątki ${ }^{26}$, w tych międzynarodowych i postkolonialnych zbiorach większość rozdziałów ogranicza się do tradycji narodowych, do których przynależą autorzy - niezależnie od tego, czy są pochodzenia katalońskiego czy kanadyjskiego, algierskiego czy argentyńskiego. Odpowiedzialność za nawiązanie międzynarodowych połączeń pomiędzy tekstami

\footnotetext{
${ }^{25} \mathrm{~J}$. Baetens, World Literature and Popular Literature: Toward a Wordless Literature? [Literatura światowa i literatura popularna. W stronę literatury bez słów?], [w:] The Routledge Companion to World Literature, red. Th. D'haen, D. Damrosch, D. Kadir, New York 2011, s. 336-337.

${ }^{26}$ Zob. K. Chiaroni, Smog, Tweed and Foreign Bedevilment: Bourland's Twenty-First-Century Remake of the Sherlock Holmes Crime Story [Smog, tweed i zagraniczne zamieszanie. Dwudziestowieczna adaptacja powieści detektywistycznej o Sherlocku Holmesie według Bourlanda], [w:] The Foreign in International Crime Fiction: Transcultural Representations, red. J. Anderson, C. Miranda, B. Pezzotti, Nowy Jork 2012, s. 137139; E. Erdmann, Nationality International: Detective Fiction in the Late Twentieth Century [Narodowość międzynarodowa. Proza detektywistyczna pod koniec dwudziestego wieku], [w:] Investigating Identities: Questions of Identity in Contemporary International Crime Fiction, red. M. Krajenbrink, K.M. Quinn, Amsterdam 2009, s. 11-26; S. Mathur, Holmes's Indian Reincarnation: A Study in Postcolonial Transposition [Indyjskie wcielenie Holmesa. Studium postkolonialnej transpozycji], [w:] Postcolonial Postmortems: Crime Fiction from a Transcultural Perspective, red. Ch. Matzke, S. Muhleisen, Amsterdam 2006, s. 87-108.
} 
oraz autorami w dużej mierze spoczywa na redaktorach tych zbiorów oraz oczywiście czytelnikach, którzy przeczytają więcej niż jeden rozdział²7.

Wyjątek od podejścia ściśle związanego z narodowością można znaleźć w pracy niemieckiej naukowczyni Evy Erdmann, która jest jedną z niewielu krytyczek skupiających się na pojęciu światowej prozy kryminalnej ${ }^{28}$. Podobnie jak Pettersson, Erdmann opowiada się za podejściem inkluzywnym. W Topographical Fiction: A World Map of International Crime Fiction proponuje naniesienie na mapę warunków, w jakich rozgrywają się powieści kryminalne, aby „przedstawić międzynarodowy zasięg prozy kryminalnej i, co nie mniej ważne..., pokazać luki w ogólnym świecie miejsc zbrodni”29. Przekonuje, że taka mapa pozwala odkryć obecność lub nieobecność kryminałów kenijskich czy koreańskich oraz wskazać miejsca, w których dochodzi do koncentracji kryminałów: na przykład w Nowym Jorku, Londynie, Barcelonie, Paryżu, Kapsztadzie czy Buenos Aires, a także dojrzeć, jak różni autorzy opisują te miejsca. Atlas świata prozy kryminalnej według Erdmann jest ciekawą propozycją, ale ma także swoje ograniczenia. W jakim miejscu takiej mapy znalazłyby się powieści Eda McBaina z serii 87th Precinct osadzone w fikcyjnym mieście Isola? Gdzie dokładnie umieścilibyśmy Christie’s St. Mary Mead, skąd pochodzi panna Jane Marple? Co więcej, mimo że Erdmann otwiera badania nad prozą kryminalną na teksty z całego świata, do pewnego stopnia umieszcza je w innych ramach narodowych, przypisując narodowość locus criminalis („Nationality” 12). Przypisuje narodowość miejscu, w którym jest osadzona narracja kryminału, bez względu na fakt, czy sam autor pochodzi z danego kraju. W ten sposób Erdmann sugeruje, że seria Roberta Wilsona o Javierze Falcónie osadzona w Sewilli „może być przypisana geograficznie do wielokrotnej kategorii: literatury hiszpańskiej brytyjskiego pochodzenia" ${ }^{\prime 3}$. Wilson jednak tworzy także literaturę portugalską w przypadku Śmierci w Lizbonie (1999) oraz, podążając za klasyfikacją Erdmann, napisał także najbardziej znane dzieło literatury Beninu - powieść z serii o Brusie Medwayu osadzoną w Afryce Zachodniej.

Ten powrót do narodowości w obrębie badań nad międzynarodową prozą kryminalną podkreśla trudności zastosowania podejścia inkluzywnego w praktyce. Historia lub mapa świata prozy kryminalnej byłaby ogromnym przedsięwzięciem, biorąc pod uwagę, że tysiące kryminałów powstają każdego roku w samych Stanach Zjednoczonych, a jeśli włączmy do tego również kryminały wydawane w każdym innym miejscu, to oczywiste, że taka historia, a nawet mapa jest projektem niemożliwym. W kontekście tak przytłaczającego zadania, łatwo zrozumieć, dlaczego badacze wolą pozostać w bezpiecznych granicach narodowej tradycji literackiej.

Mimo tych trudności można przyjąć podejście literatury światowej w przypadku prozy kryminalnej, ale nie poprzez czytanie większej liczby powieści. Nawet inkluzywne poglądy Petterssona nie

\footnotetext{
${ }^{27}$ Tak samo było ze studiami tak zwanej europejskiej prozy kryminalnej, na przykład Crime Scenes: Detective Narratives in European Culture Since 1945 [Miejsca zbrodni. Narracje detektywistyczne w kulturze europejskiej od 1945 roku] (2000) pod redakcją A. Mullen i E. O’Beirne’a, które zawiera tylko jeden artykuł rozpatrujący prozę w więcej niż jednym kraju.

${ }^{28}$ Pionierzy na tym polu to między innymi geograf George Demko, który nauczał i pisał wiele o ewolucji prozy kryminalnej na całym świecie, oraz Nina King i Robin W. Winks, którzy napisali Crimes of the Scene (1997) będące książkowym przewodnikiem po prozie kryminalnej z całego świata.

${ }^{29}$ E. Erdmann, Topographical Fiction: A World Map of International Crime Fiction [Fikcja topograficzna. Światowa mapa międzynarodowej prozy kryminalnej], „The Cartographic Journal” 2011, 48.4, s. 279.

${ }^{30}$ Tamże, s. 277.
} 
oznaczają, że naukowcy powinni się starać przeczytać każdy kryminał, jaki kiedykolwiek opublikowano, by móc się uważać za ekspertów w tej dziedzinie. Pettersson porównuje raczej badanie literatury światowej do historii światowej, przekonując, że podobnie jak „oczekiwalibyśmy od historyka, niezależnie od jego czy jej specjalizacji, że będzie dysponować pewną skromną wiedzą $z$ historii światowej”31 , badacze mogą i powinni pracować na mniejszych fragmentach ${ }^{32}$. Te „mniejsze fragmenty" nie powinny być ograniczone przez to, co Pettersson nazywa „kulturalną klaustrofobią" literatur narodowych ${ }^{33}$, tak jak większość rozdziałów składających się na wcześniej wspomniane zbiory międzynarodowej i postkolonialnej prozy kryminalnej. Pettersson namawia za to badaczy literatury, by przezwyciężali „ryzyko zaściankowości w poglądach i pracach badaczy oraz krytyków" poprzez zestawianie powieści z różnych tradycji i umożliwianie im dialogu, a czasem nawet sporów $w^{34}$. Stosując transkulturowe podejście Petterssona do badań nad prozą kryminalną, badacze mogą - zamiast badać rozwój kryminału w konkretnej tradycji narodowej - z korzyścią analizować ewolucję poszczególnych podgatunków, takich jak murder mystery, hardboiled, powieść szpiegowska i tak dalej, w różnych krajach i językach, lub też badać występowanie nowych tropów literackich: na przykład charakteryzować postaci kobiecych detektywów na całym świecie.

Moretti zauważył, że „literatura światowa nie jest obiektem, lecz problemem, i to problemem, który domaga się nowej krytycznej metody" ${ }^{35}$. Podobnie Damrosch twierdzi, że literatura światowa jest nie tyle obiektem badań, kanonem wielkich dzieł do przeczytania, co raczej praktyką lekturową, sposobem analizy tekstów literackich poza kulturową i literacką tradycją, z której pochodzą ${ }^{36}$. Praktyka czytania światowej prozy kryminalnej wymaga przesunięcia obiektu badań z produkcji na jej konsumpcję. A więc z pisarzy na czytelników.

Badając prozę kryminalną jako literaturę światową, nie powinniśmy zupełnie porzucać studiowania pisarzy kryminałów w ich kontekście narodowym, ponieważ zrozumienie autorów świadomie piszących w ramach konkretnej tradycji narodowej jest równie istotne. Celem tego artykułu jest propozycja, by traktować prozę kryminalną w taki sam sposób, jak robi to wielu jej czytelników. Czytelnicy rzadko czytają powieści pisarzy pochodzących z tylko jednego kraju. Zwykle wolą się raczyć wieloma tekstami tworzonymi przez autorów z różnych krajów lub/i pisarzy osadzających swoje powieści w różnych zagranicznych lokalizacjach ${ }^{37}$. Wielu czytelników prozy kryminalnej czyta ten gatunek w światowy sposób, więc aby rozwinąć badania nad prozą kryminalną jako literaturą światową, badacze muszą zbudować sobie praktykę analizy odzwierciedlającą praktykę czytelniczą.

Taka analiza opiera się na potrzebie budowania połączeń pomiędzy dziełami i ich twórcami. Italo Calvino twierdzi, że badanie literatury „to zawsze dialog wielu głosów, które krzyżują się

\footnotetext{
${ }^{31}$ Anders Pettersson, Transcultural..., s. 466.

${ }^{32}$ Tamże, s. 467.

${ }^{33}$ Tamże, s. 464 .

${ }^{34}$ Tamże, s. 466 .

${ }^{35}$ F. Moretti, Przypuszczenia..., s. 133.

${ }^{36} \mathrm{D}$. Damrosch, What is world literature?, s. 297.

${ }^{37}$ Zob. M. Schreier, The 'Nation' in Crime: Does the Reader Care? [„Naród” w kryminale. Czy czytelnika to obchodzi?], [w:] Crime and Nation: Political and Cultural Mappings of Criminality in New and Traditional Media, red. A. Immacolata, E. Erdmann, Trier 2009, s. 37-51.
} 
i odpowiadają sobie w obrębie literatury oraz poza nią" ${ }^{38}$. W ten sposób celem badania prozy kryminalnej z perspektywy literatury światowej staje się ustanowienie dialogu pomiędzy pisarzami oraz tekstami w poprzek narodowych, kulturowych, językowych i czasowych granic. Do nawiązania tego dialogu niezbędna jest triangulacja między światem, tekstem a czytelnikiem. Jak ujął do David Damrosch:

Kiedy stosujemy metodę triangulacji pomiędzy naszą obecną sytuacją a ogromną różnorodnością kultur wokół nas i przed nami, nie widzimy dzieł literatury światowej tak bogato otoczonych ich własnym kontekstem kulturowym, jak miałoby to miejsce podczas lektury tych tekstów w obrębie ich własnych tradycji. Jednak pewien dystans wobec własnej tradycji pomaga nam docenić sposoby, w jakie dzieło literackie sięga poza swoje miejsce pochodzenia. Jeżeli zaś potem obserwujemy siebie patrzących na dzieło wyabstrahowane od jego źródła, robimy kolejny krok naprzód ${ }^{39}$.

Proces triangulacji według Damroscha można z powodzeniem zastosować do badań prozy kryminalnej jako literatury światowej. W praktyce, skupienie na badaniach literatury światowej definiuje się zwykle na trzy sposoby: (1) jako badanie klasycznych utworów z całego świata, (2) jako arcydzieła literatury z różnych tradycji narodowych oraz (3) jako okna na różne kultury. Choć można wskazać argumenty przemawiające za stworzeniem kanonu arcydzieł światowej prozy kryminalnej, które powinien znać każdy badacz, badanie prozy kryminalnej jako literatury światowej najlepiej wpisuje się w tę trzecią kategorię - okna na różne kultury i społeczeństwa. Jak twierdzą Anderson, Miranda oraz Pezzotti, rozprzestrzenianie się kryminałów po całym świecie oznacza, że prozę kryminalną można rozważać jako „nową postać pisarstwa podróżniczego" (1), choć do miejsc i wydarzeń, których czytelnik nie chciałby doświadczyć osobiście.

Będąc rodzajem pisarstwa podróżniczego, kryminały określają, w jaki sposób czytelnicy zbierają doświadczenia $\mathrm{z}$ dużych i małych miast oraz wiosek $\mathrm{w}$ nich opisanych, a jednocześnie skupiają uwagę na tym, jak konkretne społeczności i kultury przedstawiają transgresję oraz jej przejawy. Heather Worthington twierdzi:

[a] przestępstwo oznacza naruszenie kodu danej społeczności i wymaga odpowiedzi w obrębie tego kodu. Ten kod zawsze opiera się na przepisach oraz prawie. W efekcie, pokazując przestępstwa i kary, czy to przywoływane, czy zaledwie przeczuwane, powieści detektywistyczne niezmiennie ukazują obraz danego porządku społecznego oraz jego system wartości, który pomaga go utrzymać. Nazywając dane miejsce i przywołując socjoekonomiczny porządek, który się tam utrzymuje, potwierdzają wręcz, że transgresja bez kodu jest niemożliwa, bo żadne wykroczenie nie istnieje bez społeczności, która je potępia ${ }^{40}$.

Kryminały pozwalają nam zatem zrozumieć związek pomiędzy przestępstwem a społecznością w powszechnym wyobrażeniu. Kto zginął, gdzie, jak, z czyich rąk, i w jaki sposób śledztwo rozwiązuje sprawę lub nie; jaka kara, jeśli jakaś w ogóle, zostaje wymierzona przestępcy - to wszystko są czynniki, które mogą ukształtować sposób, w jaki dana społeczność rozumie transgresję. Zdaniem Caweltiego „akt przestępstwa zaburza tkankę społeczną i detektyw musi użyć swoich

${ }^{38}$ I. Calvino, Letters, 1941-1985. Selected and with an Introduction by Michael Wood [Listy, 1942-1985. Wybrane i poprzedzone wstępem Michaela Wooda], przeł. M. McLaughlin, Princeton 2013, s. 412.

${ }^{39}$ D. Damrosch, What is world literature?, s. 300.

${ }^{40} \mathrm{H}$. Worthington, Key Concepts in Crime Fiction [Kluczowe pojęcia w prozie kryminalnej], Basingstoke 2011, s. $120-121$. 
wyjątkowych umiejętności śledczych, aby zszyć ją na nowo. W tym procesie zdolny pisarz może ujawnić pewne aspekty kulturowe, które w innych okolicznościach pozostają ukryte" ${ }^{\text {11 }}$. Kiedy transgresja jest uwarunkowana kulturowo, narodowy kontekst kryminału zyskuje na znaczeniu i nie jest wcale przestarzałą kategorią w przypadku adaptacji podejścia literatury światowej. Jednak podczas gdy podejście narodowe bada transgresję w kontekście narodowym, podejście literatury światowej poszukuje przestępstw poza granicami państwa, aby porównać je i zestawić je z przypadkami przestępstw oraz reakcji na nie w wielu różnych kontekstach.

Krytycy podkreślają, że badanie konkretnego gatunku może wspomóc analizę tekstów w różnych tradycjach literackich, ponieważ konwencje określające każdy gatunek „odgrywają znaczącą rolę w tworzeniu dzieł i kształtowaniu oczekiwań ich odbiorców"42. Jak sugeruje Damrosch, „możemy się wiele dowiedzieć o kulturze, przyglądając się, które elementy danej tradycji podkreśla, i jak używają ich jej autorzy"43. Moretti jest podobnego zdania; przekonuje, że „morfologia komparatystyczna jest tak fascynującym polem”, ponieważ „badając zmienność form, odkrywamy zmienność władzy symbolicznej w różnych przestrzeniach" ${ }^{44}$. Choć w swoim przykładzie Damrosch skupia się na formach kultury wysokiej takiej jak dramat i epika, to podejście skoncentrowane na gatunku można zastosować również w badaniach prozy popularnej. Kryminał, ze swoimi typologiami i topoi formulae, stanowi tu doskonały przykład. Gelder zauważa, że prawdopodobnie nie ma bardziej schematycznego rodzaju prozy popularnej od narracji kryminalnych i twierdzi, że należy włożyć dużo pracy w rozróżnienie tego typu dzieł w zależności od ich bohaterów i miejsc ${ }^{45}$. Podczas analizy prozy kryminalnej w obrębie literatury światowej te powtarzalne i schematyczne aspekty gatunku tak często wyśmiewane przez badaczy literatury, stają się cechami pozytywnymi.

Jaki kierunek mogą objąć badania światowej prozy kryminalnej? Do pewnego stopnia zarówno inkluzywne, jak i ekskluzywne podejście do badań literatury światowej można zastosować z korzyścią w badaniu kryminałów z całego świata. Mimo że nie trzeba żadnego kryminału wykluczać, naukowcy powinni skupić się na łatwiejszych do zaklasyfikowania elementach ze względu na aspekty praktyczne. Jak już wspomniano wcześniej, podejście ewolucyjne może się skupiać na przyswajaniu i adaptacji takich gatunków, jak murder mystery, hardboiled czy thriller szpiegowski na całym świecie. W takim podejściu można również badać zastosowanie konkretnych narzędzi literackich w czasie i miejscu, podobnie jak w locked-room mystery [tajemnica zamkniętego pokoju] po raz pierwszy zastosowanym przez Edgara Allana Poego w Zabójstwie przy Rue Morgue (1841), a później rozwiniętym przez Arthura Conan Doyle’a w powieści Nakrapiana przepaska niesie śmierć (1892) oraz Dolinie trwogi (1914-15); a także w Le Mystère de la chambre jaune (opublikowanej jako Tajemnica żóttego pokoju, 1908) Gastona Leroux, a bardziej współcześnie w Män Som Hatar Kvinnor (2005; opublikowanej jako Dziewczyna z tatuażem, 2008) Stiega Larssona, w której wyspa Hedeby staje się „zamkniętym pokojem”, gdy jedyne połączenie $z$ lądem - most - zostaje odcięte w wyniku wypadku samochodowego.

${ }^{41}$ J.G. Cawelti, Detecting..., s. 55.

${ }^{42} \mathrm{D}$. Damrosch, What is world literature?, s. 47.

${ }^{43}$ Tamże.

${ }^{44} \mathrm{~F}$. Moretti, Przypuszczenia..., s. 144.

${ }^{45} \mathrm{~K}$. Gelder, Popular Fiction..., s. 63. 
Innym podejściem może być badanie pewnych wydarzeń historycznych lub zjawisk poprzez pryzmat konwencji gatunku, jakim jest kryminał - przede wszystkim jego skupienia na prawie i wymiarze sprawiedliwości. Jednym $\mathrm{z}$ takich przykładów jest badanie kryminałów, które zajmują się „przeszłością Narodowego Socjalizmu oraz jego spuścizny w epoce powojennej” przeprowadzone przez brytyjską naukowczynię Katharinę Hall ${ }^{46}$. W swojej pracy Hall zidentyfikowała ponad 150 transnarodowych kryminałów - w tym angielskich, niemieckich, czeskich, polskich i kanadyjskich - które poruszają ten temat. Zdaniem Hall badanie pewnego zdarzenia historycznego lub okresu, takiego jak rządy Narodowego Socjalizmu w Niemczech i Europie, poprzez prozę kryminalną pisarzy z różnych środowisk i narodowości może dostarczyć „odkrywczych przedstawień egzekwowania prawa”, a także „zachęcania czytelników, poprzez postać nazistowskiego detektywa, do krytycznego postrzegania kwestii prawa, odpowiedzialności moralnej i winy"47.

Wymiar sprawiedliwości w okresach przejściowych w społeczeństwach byłych dyktatur jest blisko związany z badaniami Hall. W ostatnich latach wystąpił zalew kryminałów z krajów, które cierpiały wskutek dyktatury, na przykład La pregunta de sus ojos Eduarda Sacheri (Argentyna), Los amigos del crimen perfecto Andrésa Trapiello (Hiszpania), Purge (Estonia) fińskiej pisarki tworzącej po estońsku Sofii Oksanen, oraz seria Bernarda Schlinka i Waltera Poppa o Gerhardzie Selfie (Niemcy). Analiza tych powieści z perspektywy literatury światowej dostarcza wglądu w różnorodne sposoby, na które pisarze wykorzystują ten gatunek, by umieścić dawne wydarzenia w obrębie wymiaru prawa, co stanowi jego gatunkową podstawę. W ten sposób tego typu powieści nie tylko starają się przezwyciężyć zinstytucjonalizowane zacieranie pamięci, odkrywając stłumione wspomnienia, stanowią także próbę zwrócenia uwagi na historyczny wymiar sprawiedliwości z punktu widzenia litery prawa.

Od nieśmiałych początków w pierwszych dekadach dwudziestego wieku, ale szczególnie od lat siedemdziesiątych do dziś, pisarki tworzyły kryminały z postacią kobiety detektywa - czy to amatorki, czy zawodowca, czy pracowniczki policji - jako sposób badania kwestii związanych z opresją kobiet, takich jak przemoc fizyczna i psychiczna, gwałty, prostytucja, instytucjonalna oraz społeczna dyskryminacja i kwestie kobiece. Przyswajając punkt widzenia literatury światowej, który skupia się na przedstawianiu postaci kobiecych jako ofiary, przestępcy, detektywa, oraz w innych rolach, w różnych kulturach i społecznościach, proza kryminalna może wiele powiedzieć o tym, jak są postrzegane kwestie dotyczące kobiet oraz jak wygląda ich pozycja społeczna. Podobnie punkt widzenia literatury światowej można zastosować do pojęć rasy, homoseksualizmu, klasy oraz grup etnicznych w różnych kulturach i krajach.

I na koniec - perspektywa literatury światowej może być z korzyścią zastosowana w odbiorze pewnych powieści w różnych częściach świata. Dlaczego niektóre powieści cieszą się międzynarodowym sukcesem, a inne nie? Dlaczego trylogia Millennium Larssona rozbrzmiewa w tylu

\footnotetext{
${ }^{46} \mathrm{~K}$. Hall, The 'Nazi Detective' as Provider of Justice in Post-1990 British and German Crime Fiction: Philip Kerr's "The Pale Criminal", Robert Harris's "Fatherland", and Richard Birkefeld and Goran Hachmeister's "Wer ubrig bleibt, hat recht” [„Nazistowski detektyw” jako wymiar sprawiedliwości w brytyjskiej i niemieckiej prozie kryminalnej po 1990 roku: „The Pale Criminal” Philipa Kerra, „Fatherland” Roberta Harrisa oraz „Wer ubrig bleibt, hat recht” Richarda Birkefelda i Gorana Hachmeistera], „Comparative Literature Studies” 2013, nr 50.2, s. 288.

${ }^{47}$ Tamże, s. 311.
} 
językach i kulturach? Jak krytycy, pisarze i czytelnicy reagowali na książki Conan Doyle’a, Christie, Hammetta lub Spillane’a? Badanie recepcji poszczególnych tekstów, takie jak podjęte przez Margrit Schreier, może czerpać korzyści z recenzji czytelników i witryn księgarzy, stron i blogów fanów, aby zyskać wgląd w to, dlaczego powieści podróżują poza swoją ojczystą kulturę.

Tłumaczka Edith Grossman opisuje literaturę narodową jako „zawężający, ograniczający koncept oparty na rozróżnieniu pomiędzy swoim a obcym"48. Uważa, że przełamać te ograniczenia potrafi przekład literacki, ponieważ „zapewnia możliwość spójnego, jednolitego doświadczania literatury w światowej mnogości języków”, a jednocześnie uświęca „różnice pomiędzy językami oraz wiele odmian ludzkiego doświadczenia i percepcji, które mogą wyrażać" ${ }^{\prime 9}$. Grossman nie opowiada się za całkowitym odrzuceniem badań tradycji narodowej - zauważa, że literatura narodowa jest „z pewnością uzasadnionym i przydatnym rozróżnieniem w pewnych dziedzinach i okolicznościach" ${ }^{\text {50 }}$. Jak twierdzi Worthington, proza kryminalna jest ściśle związana z tym, jak każda kultura lub społeczność stwarzają i przedstawiają przestępczość. Pomysł Grossman na badanie prozy kryminalnej co prawda przede wszystkim łączy prozę kryminalną z konkretnym miejscem, ale prowadzi też do wniosku, że badanie kryminałów w oryginale lub w przekładzie pomiędzy tradycjami narodowymi, zamiast w ich obrębie, może dać nowy wgląd w związek pomiędzy konkretnymi społecznościami i transgresją. A zatem podejście z perspektywy literatury światowej ma w sobie potencjał, by rozwijać nowe interpretacje oraz bardziej zróżnicowane rozumienie tego naprawdę globalnego gatunku.

\section{Przełożyła Anna Tomczyk}

${ }^{48}$ E. Grossman, Why Translation Matters [Dlaczego przekład ma znaczenie], New Haven 2011, s. 17.

${ }^{49}$ Tamże.

${ }^{50}$ Tamże. 


\title{
SEOWA KLUCZOWE:
}

proza kryminalna

\section{KRYMINAE}

\begin{abstract}
AbStrakt:
Celem tego artykułu jest przyjrzenie się prozie kryminalnej (crime fiction) w ramach koncepcji literatury światowej. Autor przekonuje, że badanie tradycji narodowych może nas wyłączyć z dialogu pomiędzy granicami i językami, pomiędzy tekstami i pisarzami. Proponuje praktykę czytania, która ma rozwinąć bardziej zróżnicowane rozumienie tego naprawdę globalnego gatunku.
\end{abstract}




\section{literatura międzynarodowa}

\section{NOTA O AUTORzE:}

Stewart King - wykłada na Filologii Hiszpańskiej i Latynoamerykańskiej, a także koordynuje program Literatur Międzynarodowych na Monash University w Australii. Opublikował wiele tekstów na temat współczesnych utworów katalońskich i hiszpańskich, w szczególności prozy kryminalnej, a w tej chwili kończy pracę nad monografią dotyczącą tożsamości kulturowej i prozy kryminalnej z Hiszpanii. 